\title{
Efektivitas Model Problem Based Learning Berbantuan LKPD Terhadap Hasil Belajar Muatan Pelajaran IPA
}

\section{Made Gede Swiyadnya ${ }^{1 *}$, I Made Citra Wibawa ${ }^{2}$, I Kade Agus Sudiandika ${ }^{3}$}

\author{
${ }^{1}$ Pendidikan Profesi Guru, Pendidikan Guru Sekolah Dasar, Universitas Pendidikan Ganesha, Singaraja, Indonesia \\ 2 Pendidikan Guru Sekolah Dasar, Universitas Pendidikan Ganesha, Singaraja, Indonesia \\ ${ }^{3}$ Sekolah Dasar Negeri 3 Temukus, Singaraja, Indonesia
}

\section{ART I CLE I N F O}

Article history:

Received May 09, 2021

Revised May 15, 2021

Accepted June 23, 2021

Available online Kuly 25, 2021

Kata Kunci:

PBL, Hasil Belajar, IPA, LKPD

Keywords:

PBL, Learning Outcomes,

Science, Student Worksheet

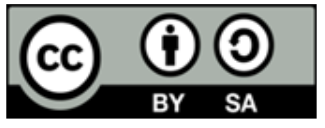

This is an open access article under the CC BY-SA license.

Copyright $\left({ }_{0} 2021\right.$ by Author. Published by Universitas Pendidikan Ganesh

\begin{abstract}
A B S T R A K
Kepaduan pembelajaran pada kurikulum 2013 ternyata kurang berdampak pada muatan pelajaran IPA yang dilaksanakan di sekolah. Minimnya inovasi pembelajaran mengakibatkan siswa tidak terlibat secara aktif dalam proses pembelajaran dan belum dikondisikan untuk belajar mengeksplorasi materi pelajaran yang diberikan sehingga terkesan monoton dan siswa menjadi bosan. Sesuai dengan permasalahan yang dihadapi siswa dengan gambaran di atas perlu adanya inovasi penggunaan model pembelajaran yang dapat meningkatkan antusias siswa salah satunya dengan pembelajaran yang menuntut siswa untuk berpikir kritis. Penelitian ini bertujuan mengetahui Efektivitas model Problem Based Learning berbantuan LKPD untuk meningkatkan hasil belajar siswa pada pembelajaran IPA Kelas V. Subjek penelitian adalah siswa kelas $V$ sebanyak 28 siswa. Selanjutnya objek penelitian ini adalah hasil belajar muatan pelajaran IPA siswa setelah mengikuti pembelajaran dengan penerapan model Problem Based Learning berbantuan LKPD. Metode pengumpulan data yang digunakan untuk mengumpulkan hasil belajar siswa adalah metode tes. Teknik analisis data dalam penelitian tindakan kelas ini adalah teknik analisis deskripsif kuantitatif. Hasil penelitian menunjukan bahwa, rata-rata hasil belajar pada siklus I adalah 68,21 dan meningkat pada siklus II menjadi 79,64. Daya serap siswa pada siklus sebesar $68,21 \%$ dan meningkat pada siklus II menjadi $79,64 \%$ serta ketuntasan belajar siswa pada siklus I sebesar $64 \%$ dan meningkat pada siklus II menjadi 82\%. Jadi, model Problem Based Learning berbantuan LKPD efektif dalam meningkatkan hasil belajar muatan pelajaran IPA siswa.
\end{abstract}

\section{A BS T R A C T}

The integration of a curriculum turned out to have less impact on the content of science lessons implemented in schools. The lack of learning innovation caused students to be minimally actively involved in the learning process and students had not been conditioned to learn to explore the subject matter provided so that it seemed monotonous and students became bored. Following the problems faced by students with the description above, it is necessary to innovate the use of learning models that can increase student enthusiasm, one of which is learning that requires students to think critically. This study aims to determine the effectiveness of the Problem Based Learning model assisted by student worksheet (LKPD) to improve student learning outcomes in learning science class 5. The subjects of this study were 28 fifth grade students. Furthermore, the object of this research is the learning outcomes of students science lesson content after participating in learning by applying the Problem Based Learning model assisted by student worksheets. The data collection method used to collect student learning outcomes is the test method. The data analysis technique in this classroom action research is descriptive quantitative analysis technique. The results showed that the average learning outcomes in the first cycle was 68.21 and increased in the second cycle to 79.64. The absorptive capacity of the students in the first cycle of $68.21 \%$ and increased in the second cycle to $79.64 \%$ and completeness of students in the first cycle by $64 \%$ and increased in the second cycle to $82 \%$. So, the Problem Based Learning model assisted by LKPD can improve students learning outcomes of science content. 


\section{PENDAHULUAN}

Pelajaran IPA merupakan salah satu muatan pelajaran wajib yang diterapkan mulai dari jenjang sekolah dasar. Pembelajaran IPA adalah bidang ilmu yang mengkaji alam semesta dan segala isinya beserta usaha manusia untuk mengungkap segala misteri yang bergantung pada minat, keyakinan, dan ketekunan melalui aktivitas mental, kemampuan hingga teknik dalam mengendalikan dan memastikan untuk menguji kenyataan yang terjadi (Nelvianti \& Fitria, 2020). Hal ini berarti, IPA bukan hanya dominasi informasi yang diusulkan sebagai realitas dan ide tetapi juga siklus memfasilitasi untuk bekerja dengan siswa dalam berpikir secara mendasar dan cakap menangani masalah serta menghadapi ukuran pembelajaran yang signifikan (Wardani, Rifai, \& Mandalwati, 2017; Syafriana, 2017). IPA digambarkan sebagai suatau muatan pelajaran dapat digunakan oleh siswa dalam menelaah dan menggali informasi mengenai fenomena alam yang ada melalui proses ilmiah. Berdasarkan pemaparan mengenai pembelajaran IPA, dapat disimpulkan bahwa pembelajaran IPA ialah bidang ilmu pengetahuan tentang alam semesta dan substansinya yang digunakan untuk mengungkap semua keajaiban normal yang ada berdasarkan minat, kepastian, dan tanpa lelah melalui latihan pengungkapan dan siklus logis untuk menguji kenyataan yang terjadi disekitar. Pendidikan IPA terpadu di sekolah dasar mengizinkan siswa berproses melalui pengalaman langsung, sehingga mampu meningkatkan kemampuannya dalam menerima, menyimpan, serta mempraktikkan konsep yang dipelajarinya secara merata, bermakna, otentik, serta aktif (Sufiyanto, 2020:13). Hal ini berarti pembelajaran IPA terpadu pada kurikulum 2013 memberikan peluang bagi guru untuk mengembangkan pembelajaran yang utuh selain itu siswa dapat belajar dengan terarah dan sistematis. Proses Pembelajaran IPA di SD dipadukan dalam pembelajaran tematik. IPA terpadu di SD dalam program pendidikan menggunakan penilaian yang tegas dan berjangkauan luas atau secara tegas ditunjukkan dengan tujuan agar pendidik melakukan penilaian yang wajar terhadap bidang-bidang perasaan, psikologis, dan psikomotorik (Setiadi, 2016).

Namun, pembelajaran IPA pada penerapannya di sekolah dasar memiliki beberapa kendala dan permasalahan. Hasil observasi yang dilakukan terhadap kegiatan pembelajaran muatan IPA siswa kelas V SD Negeri 5 Manistutu semester I tahun pelajaran 2020/2021 yaitu adanya masalah dalam proses pembelajaran IPA. Beberapa masalah tersebut yaitu lebih banyak siswa yang kurang perhatian terhadap penyampaian materi yang dijelaskan oleh guru. Hal tersebut menggambarkan bahwa siswa kurang fokus dan antusiasme siswa kurang. Secara umum hal ini sesuai dengan survey TIMMS (Trens in Student Achievement in Mathematics and Science) yang menyatakan bahwa Indonesia berada pada posisi yang sungguh memprihatinkan yaitu peringkat 45 dari 48 negara untuk hasil belajar IPA (Wicaksono, Jumanto, \& Irmade, 2020). Fakta di atas diungkapkan oleh beberapa penelitian yang telah dilakukan sebelumnya yang menyebutkan bahwa pembelajaran IPA belum dikelola dengan baik dan beberapa faktor penyebab rendahnya hasil belajar yaitu, belum diterapkannya inovasi pembelajaran, pembelajaran cenderung pada domain ingatan, materi pelajaran disajikan hanya melalui satu metode, dan pembelajaran belum berorientasi pada peserta didik (Putri, Swatra, \& Tegeh, 2018; Silitonga, 2020). Permaslahan tersebutu berarti siswa kurang terlibat secara aktif dalam proses pembelajaran karena model dan metode yang digunakan oleh guru tidak memungkinkan siswa untuk ikut terlibat dalam proses pembelajaran. Siswa belum dikondisikan untuk belajar untuk mengeksplorasi materi pelajaran yang diberikan sehingga terkesan moton dan siswa menjadi bosan serta berakibat pada hasil belajar muatan pelajaran IPA siswa belum maksimal.

Eskalasi hasil belajar dilihat melalui pelaksanaan pendidikan dengan memanfaatkan model ataupun tata cara pendidikan yang cocok dengan ciri khas siswa (Pramudya, Kristin, \& Anugrahen, 2019). Hal ini menandakan perlu adanya inovasi pembelajaran sesuai dengan karakteristik muatan IPA yang menuntut siswa untuk berpikir kritis sesuai dengan pembelajaran abad 21 dalam menerapkan sikap ilmiahnya. Pendidikan berbasis permasalahan dengan 4C (critical thinking, creativity, collaboration, dan communication) akan menuntut siswa memiliki keahlian berpikir kritis, bekerja sama, kreatif, serta tumbuhnya komunikasi antar siswa (Ekawati, Dantes, \& Marhaeni, 2019). Pernyataan tersebut menjelaskan bahwa penggunaan model pembelajaran yang dapat meningkatkan antusias siswa salah satunya dengan pembelajaran yang menuntut siswa untuk berpikir kritis dengan menerapkan pembelajaran yang berbasis pada masalah. Model pembelajaran berbasis masalah atau Problem Based Learning mengajak peserta didik untuk mampu memecahkan permasalahan dalam suatu pembelajaran dengan menekankan pada keahlian berpikir siswa dalam proses kognitif yang mengaitkan kemampuan mental dalam mengatasi sebuah kasus yang nyata sehingga mampu membangun pengetahuannya secara mandiri (Huda \& Abduh, 2021; Wahyuningtyas \& Kristin, 2021; Yunitasari \& Hardini, 2020). Dari hal tersebut terdapat Beberapa penelitian membuktikan yaitu, penelitian pertama yang memperoleh hasil penelitian bahwa model Problem Based Learning berpengaruh pada peningkatan hasil belajar IPA Tiarini, Dantes, \& Yudiana, (2019). Penelitian kedua, yang memperoleh hasil bahwa pembelajaran muatan IPA dengan model Problem Based Learning berpengaruh positif dan pembelajaran menjadi lebih bermakna sehingga mampu meningkatkan kemampuan memecahkan masalah dan hasil belajar kognitif siswa Supiandi \& Julung (2016). Berdasarkan pendapat tersebut, dapat disimpulkan bahwa peningkatan hasil belajar muatan IPA dapat dilakukan dengan menerapkan model Problem Based Learning karena pembelajarannya yang berpusat pada permasalahan melalui penemuan yang membutuhkan kemampuan intuisi tingkat tinggi dalam siklus intelektual 
yang dapat membantu siswa mempersiapkan data instan dalam jiwa mereka dan memilah wawasan mereka sendiri yang terkait dengan dunia sosial dan faktor lingkungannya untuk memperluas informasi penting atau kompleks sehingga tercipta pembelajaran yang berpusat pada siswa.

Model PBL terdiri atas 5 langkah ialah orientasi siswa pada permasalahan, mengorganisasikan siswa dalam belajar, tutorial penyelidikan perorangan ataupun kelompok, pengembangan serta penyajian hasil karya, serta analisis dan penilaian hasil karya (Meilasari, M, \& Yelianti, 2020; Rosidah, 2018). Melalui sintak tersebut model PBL seyogyanya dapat membangun keterampilan pemecahan masalah dan diandalkan untuk melibatkan siswa agar mandiri dan siap menghadapi setiap masalah Oktaviani \& Nirmala (2018). Namun keterampilan pemecahan masalah yang dimiliki oleh siswa tidak serta merta tumbuh begitu saja pada diri siswa, sehingga dperlukan adanya media yang dapat digunakan oleh guru untuk menuntun siswa dalam memecahkan masalah dalam pembelajaran berbasis masalah (Hasanah, Pada, \& Safrida, 2021; Naimah, Winarni, \& Widiyawati, 2019). Salah satu media yang dapat digunakan untuk menuntutn siswa dalam pemecahan masalah adalah Lembar Kerja Peserta Didik (LKPD). LKPD IPA berbasis masalah sangat layak digunakan dan mendapatkan respon yang sangat baik dari peserta didik karena melalui LKPD terdapat panduan atau materi peragaan yang dapat dimanfaatkan oleh peserta didik sebagai siklus pembelajaran yang bebas untuk meningkatkan susunan, kemampuan, dan cara pandang siswa (Regita C et al., 2020; Fuadati \& Wilujeng, 2019). Melalui LKPD guru akan dipermudah untuk memandu pembelajaran dalam membentuk asosiasi yang kuat antara pendidik dan siswa sehingga pembelajaran menjadi menarik karena situasi dan kondisi sesuai dengan iklim umum Sedangkan menurut (Amali, Kurniawati, \& Zlhiddah 2019). Berdasarkan hal tersebut dapat disimpulkan bahwa Model Problem Based Learning berbantuan LKPD merupakan penerapan pembelajaran berbasis masalah dengan media dan aset pembelajaran yang dapat membantu pendidik dalam membuat kolaborasi yang sukses melalui aturan atau menunjukkan materi yang terkandung di dalamnya sehingga siswa dapat beradaptasi secara mandiri dalam meningkatkan pengaturan, kemampuan, dan mentalitasnya serta adanya LKPD akan membantu guru dalam membangun pengetahuan baru bagi siswa dalam memecahkan masalah yang akan dipecahkan melalui panduan atau langkah kerja yang ada didalamnya. Dari masalah-masalah yang ditemukan dan solusi yang telah ditentukan, maka tujuan penelitian ini adalah untuk mengetahui Efektivitas model Problem Based Learning berbantuan LKPD terhadap hasil belajar siswa pada pembelajaran IPA Kelas V di SD Negeri 5 Manistutu Tahun Pelajaran $2020 / 2021$.

\section{METODE}

Penelitian yang dilakukan merupakan jenis penelitian tindakan kelas. Penelitian Tindakan Kelas (PTK) atau classroom action research merupakan eksplorasi yang dipimpin oleh pendidik di kelas (sekolah) dimana ia mengajar dengan penekanan pada perbaikan atau perbaikan siklus dan praksis pembelajaran serta PTK merupakan usaha yang dimanfaatkan oleh pendidik untuk memperbaiki hakikat pembelajaran dengan menerapkan kemajuan pembelajaran sebagai teknik, prosedur, dan media (Fitria et al., 2019). Dengan demikian dapat disimpulkan bahwa, PTK merupakan adalah penelitian yang diarahkan oleh pengajar di ruang belajarnya untuk meningkatkan siklus dan praksis pembelajaran melalui pemanfaatan kemajuan pembelajaran sebagai teknik, metodologi, dan media. PTK sebagai suatu tindakan memiliki langkah-langkah yang harus dilakukan. Langkah-langkah yang digunakan sesuai dengan model Stephen Kemmis dan Robyn McTagart. Langkah PTK dengan model ini terdiri dari empat tahap, yaitu penyusunan (plan), kegiatan (act), persepsi (notice), dan refleksi (reflect) (Prihantoro \& Hidayah, 2019). Tindakan yang dilakukan saling berhubungan sehingga memperoleh tindak lanjut dari setiap siklusnya. Pada setiap siklus dilakukan perbaikan pembelajaran yang telah dilakukan hingga pada akhirnya hasil belajar siswa meningkat. Subyek penelitian tindakan kelas ini adalah siswa kelas V SD Negeri 5 Manistutu yang berjumlah 28 orang dengan rincian 11 orang siswa laki-laki dan 17 orang siswa perempuan. Berdasarkan permasalahan yang ditemukan, objek dari penelitian ini adalah hasil belajar muatan pelajaran IPA siswa dengan menerapkan model Problem Based Learning berbantuan lembar kerja peserta didik (LKPD). Data yang dikumpulkan pada penelitian ini adalah data kuantitatif berupa hasil belajar IPA siswa melalui metode pengumpulan data tes hasil belajar. Metode tes adalah instrumen yang digunakan untuk mengukur hasil belajar siswa dengan hasil perolehan data berbentuk angka-angka berupa data kuantitatif (Dewi \& Kristin, 2017; Zakia et al., 2018). Adapun tes yang dimaksud tertuang pada Tabel 1.

Tabel 1. Kisi-Kisi Tes Hasil Belajar Muatan Pelajaran IPA

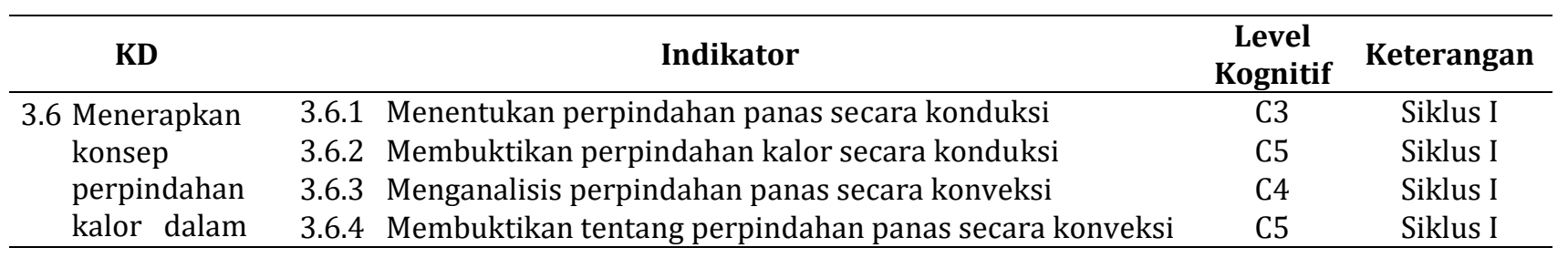




\begin{tabular}{|c|c|c|c|}
\hline KD & Indikator & $\begin{array}{c}\text { Level } \\
\text { Kognitif }\end{array}$ & Keterangan \\
\hline \multirow{9}{*}{$\begin{array}{l}\text { kehidupan } \\
\text { sehari-hari }\end{array}$} & 3.6.5 Menganalisis perpindahan panas secara radiasi & $\mathrm{C} 4$ & Siklus I \\
\hline & 3.6.6 Membuktikan tentang perpindahan panas secara radiasi & $\mathrm{C} 5$ & Siklus I \\
\hline & 3.6.7 Memahami benda-benda penghantar panas & $\mathrm{C} 2$ & Siklus II \\
\hline & 3.6.8 Memahami benda-benda penghambat panas & $\mathrm{C} 2$ & Siklus II \\
\hline & $\begin{array}{l}\text { 3.6.9 Menganalisis benda-benda yang bersifat menghambat } \\
\text { perpindahan kalor di sekitar rumah }\end{array}$ & $\mathrm{C} 4$ & Siklus II \\
\hline & $\begin{array}{l}\text { 3.6.10 Menganalisis benda-benda yang bersifat mempercepat } \\
\text { perpindahan kalor di sekitar rumah }\end{array}$ & $\mathrm{C} 4$ & Siklus II \\
\hline & $\begin{array}{l}\text { 3.6.11 Membandingkan benda-benda penghantar panas dan } \\
\text { penghambat panas }\end{array}$ & $\mathrm{C} 5$ & Siklus II \\
\hline & $\begin{array}{l}\text { 3.6.12 Menganalisis peralatan yang ada di sekitar yang bersifat } \\
\text { menghambat perpindahan kalor di sekitar tempat tinggal }\end{array}$ & $\mathrm{C} 4$ & Siklus II \\
\hline & $\begin{array}{l}\text { 3.6.13 Menganalisis peralatan yang ada di sekitar bersifat } \\
\text { mempercepat perpindahan kalor di sekitar tempat tinggal }\end{array}$ & $\mathrm{C} 4$ & Siklus II \\
\hline
\end{tabular}

Metode atau teknik analisis data yang digunakan pada penelitian ini adalah analisis deskriptif kuantitatif. Analisis yang dimaksud meliputi nilai rata-rata, daya serap siswa, ketuntasan belajar siswa, kriteria keberhasilan, dan penilaian acuan patokan. Pemeriksaan nilai rata-rata siswa digunakan untuk mengetahui pemahaman siswa dengan penanda prestasi sesuai ketuntasan belajar minimal (KBM) yang telah ditetapkan. Dari nilai rata-rata kemudian penentuan daya serap untuk mengetahui keadaan siswa terkait pemahamannya terhadap muatan pelajaran IPA melalui data hasil tes setiap siklus. Disetiap siklus tersebut dianalisis ketuntasan belajar siswa dilihat menurut ketuntasan belajar minimal (KBM) yaitu muatan pelajaran IPA SDN 5 Manistutu adalah 69. Selanjutnya ditentukan kriteria keberhasilan dan indikatornya yaitu, rata-rata sebesar 75\%, daya serap sebesar 75\%, dan ketuntasan belajar sebesar 80\%. Seluruh analisis tersebut kemudian integrasikan kedalam penilaian acuan patokan (PAP) sebagai instrumen dalam menentukan keberhasilan belajar siswa berdasarkan kategori pada tabel 2 .

Tabel 2. Kriteria Penilaia Acuan Patokan (PAP) Skala Lima Hasil Belajar Siswa

\begin{tabular}{ccc}
\hline Tingkat Penguasaan (\%) & Nilai & Kategori \\
\hline $90-100$ & A & Sangat Baik \\
$80-89$ & B & Baik \\
$65-79$ & C & Cukup \\
$55-64$ & D & Kurang \\
$0-54$ & E & Sangat Kurang \\
\hline
\end{tabular}

Penelitian ini diarahkan melalui dua siklus. Setiap siklus dilakukan dengan tiga kali pertemuan dan diakhiri dengan post-test pada akhir siklus. Berikut adalah kegiatan yang dilaksanakan pada setiap siklusnya. Pada Siklus I, dilaksanakan pembelajaran dengan menggunakan model Problem Based Learning berbantuan LKPD pada muatan pelajaran IPA Siswa Kelas V dengan beberapa langkah-langkah. Pertama, perencanaan tindakan I yaitu, merancang program pelaksanaan pembelajaran (RPP) yang konsisten dengan model Problem Based Learning, menyusun dan menyiapkan materi intruksi serta Lembar Kerja Peserta Didik (LKPD), merencanakan dan menyiapkan media atau perangkat pembelajaran yang akan digunakan sebagai gambar atau rekaman berupa video yang dapat diakses melalui WhatsApp, menyusun evaluasi pembelajaran melalui platform google form. Kedua, pelaksanaan tindakan I. Pada tahap ini rencana sistem dan situasi pelaksanaan pembelajaran akan diterapkan. Kegiatan yang diselesaikan adalah melakukan pembelajaran sesuai RPP yang telah disiapkan. Ketiga, pengamatan/pengumpulan data I. Tahap ini diidentikkan dengan pelaksanaan kegiatan di kelas. Tindakan ini menggunakan lembar observasi dan tes hasil belajar siswa. Pada tahap ini, informasi yang diperoleh diselidiki menggunakan persepsi dan tes. Keempat, refleksi I. Tahap refleksi ini direncanakan untuk secara bersama-sama menginspeksi kegiatan yang telah dilakukan pada setiap siklus, berdasarkan informasi yang telah dikumpulkan, dan kemudian mengarahkan penilaian untuk menyempurnakan kegiatan selanjutnya. Selanjutnya pemeriksaan dan penilaian efek samping dari observasi siswa yang telah dilakukan. Efek samping dari refleksi digunakan sebagai alasan untuk pengembangan dalam membuat pengaturan untuk siklus berikutnya.

Pada siklus II juga dilaksanakan pembelajaran dengan menggunakan model Problem Based Learning berbantuan LKPD pada muatan pelajaran IPA Siswa Kelas V dengan beberapa langkah-langkah. Persama, perencanaan tindakan II. Kegiatan yang dilakukan yaitu, merancang program pelaksanaan pembelajaran (RPP) yang konsisten dengan model Problem Based Learning, menyusun dan menyiapkan bahan ajar dan Lembar Kerja 
Peserta Didik (LKPD), merencanakan dan menyiapkan media atau perangkat pembelajaran yang akan digunakan sebagai gambar atau rekaman berupa video yang dapat diakses melalui Whats App dan Google Meet, menyusun jadwal pembelajaran melalui Google Calendar untuk mempersiapkan pembelajaran melalui Google Meet, menyusun evaluasi pembelajaran melalui platform Google Form. Kedua, pelaksanaan tindakan II. Pada tahap ini rencana sistem dan situasi pelaksanaan pembelajaran akan diterapkan. Kegiatan yang diselesaikan adalah melakukan pembelajaran sesuai RPP yang telah disiapkan. Ketiga, pengamatan/pengumpulan data II. Tahap ini diidentikkan dengan pelaksanaan kegiatan di kelas. Tindakan ini menggunakan lembar observasi dan tes hasil belajar siswa. Pada tahap ini, informasi yang diperoleh diselidiki menggunakan persepsi dan tes. Keempat, Refleksi II. Tahap refleksi ini direncanakan untuk meninjau secara menyeluruh kegiatan-kegiatan yang telah dilakukan pada setiap siklus, dilihat dari informasi yang telah dikumpulkan, dan setelah itu langsung melakukan tes untuk menyempurnakan kegiatan selanjutnya. Kegiatan yang dilakukan adalah investigasi dan evaluasi konsekuensi persepsi terhadap langkah-langkah yang telah dilakukan untuk memutuskan peningkatan hasil belajar siswa serta menentukan pilihan untuk siklus berikutnya.

\section{HASIL DAN PEMBAHASAN}

\section{Hasil}

Hasil belajar siswa pada pra siklus menunjukkan bahwa siswa yang dinyatakan tuntas sesuai dengan KBM yang telah ditentukan hanya mencapai $43 \%$ atau 12 dari 28 siswa. Sedangkan siswa yang dinyatakan tidak tuntas memiliki presentase yang lebih tinggi yaitu 57\% atau 16 dari 28 siswa. Hal ini menunjukan bahwa ketuntasan belajar siswa pada hasil belajar muatan pelajaran IPA sebesar $43 \%$. Presentase ketuntasan belajar ini masih sajuh dari presentase yang dikehendaki yaitu ketuntasan belajar sebanyak $80 \%$ siswa atau sebanyak 22 dari 28 siswa. Selain itu daya serap siswa masih redah dengan persentase 64,93\%. Dari hasil temuan tersebut maka diperlukan inovasi pembelajaran untuk meningkatkan hasil belajar muatan pelajaran IPA siswa kelas V melalui penerapan model Problem Based Learning berbantuan LKPD. Model Problem Based Learning berbantuan LKPD pada siklus I dan II menunjukan adanya Efektivitas hasil belajar muatan IPA dengan peningkatan yang positif. Pada Siklus I, rata-rata hasil belajar menunjukan masih dalam kategori cukup dan ketuntasan siswa masih rendah yaitu berapa pada persentase $64 \%$. Hasil tersebut menunjukan bahwa pada siklus I belum mencapai indikator penelitian yang telah ditentukan. Hasil belajar yang ditunjukan pada siklus I sudah mulai menunjukan adanya peningkatan dari kondisi awal, namun masih jauh dari indikator yang telah ditentukan. Masih redahnya hasil belajar siswa berdasarkan rata-rata, daya serap, dan ketuntasan belajar siswa pada siklus I disebabkan oleh beberapa hal diantaranya: (a) siswa belum terbiasa dengan pembelajaran berbasis masalah; dan (b) kegiatan pembelajaran daring menciptakan jarak sehingga kurangnya komunikasi multi arah. Hasil belajar yang ditunjukan pada siklus II menunjukan bahwa, kegiatan berlangsung dengan lebih baik dibandingkan dengan kegiatan pembelajaran pada siklus I. Adanya peningkatan pada siklus II terlihat dari hasil belajar siswa sudah mencapai indikator penelitian yang telah ditetapkan dan bahkan melebihinya. Tercatat ketuntasan belajar siswa telah mencapai $82 \%$. Ketercapaian hasil belajar ini menunjukan adanya peningkatan dan perbaikan dari kegiatan pada siklus I. Pembelajaran pada siklus II menunjukan bahwa, dari observasi yang telah dilakukan siswa telah terbiasa menerapkan pembelajaran berbasis masalah. Dari permasalahan tersebut siswa mulai mampu membangun pengetahuannya secara mandiri melalui percobaan yang dilakukan dengan panduan LKPD. Siswa merasa senang dan sistematis dalam memecahkan masalah dalam pembelajaran melalui panduan yang ada pada LKPD. Berdasarkan pembelajaran yang dilaksanakan pada siklsu II adapun kendala yang dihadapi secara umum tidak terlalu riskan, hanya pada sikap yang perlu dibiasakan oleh siswa dalam pembelajaran dengan berorientasi pada masalah. Siswa perlu membangun pengetahuannya dengan kegiatan menggali informasi baru melalui kegiatan membaca.

Gambaran yang jelas dapat dilihat dengan peningkatan yang telah dicapai siswa dari kegiatan pembelajaran siklus I dan siklus I dilihat pada gambar 2. Perolehan hasil belajar muatan pelajaran IPA pada gambar 2 menunjukan adanya peningkatan mulai dari rata-rata kelas pada siklus I sebesar 68,21 menjadi 79,64 pada siklus II. Selanjutnya pada daya serap siswa menunjukan peningkatan pada siklus I sebesar $68,21 \%$ menjadi $79,64 \%$ pada siklus II. Ketuntasan belajar siswa juga menunjukan adanya peningkatan pada siklus I 64\% dan pada siklus II menjadi 82\%. Adanya peningkatan ini merupakan akibat dari penerapan model Problem Based Learning berbantuan LKPD dilaksanakan dengan baik mulai dari perencanaan hingga refleksi di setiap siklusnya. Berdasarkan hasil pemaparan informasi yang telah dijelaskan, bahwa pemanfaatan model ini sangat signifikan dalam meningkatkan hasil belajar siswa dan tentunya dengan bantuan LKPD. Keberhasilan model Problem Based Learning ini dikarenakan siswa dihadapkan pada permasalahan yang autentik karena pembelajaran yang autentik tergantung pada gagasan "belajar sambil melakukan" untuk membuat iklim belajar "bergerak" yang memungkinkan siswa untuk mengambil bagian secara aktif dalam kegiatan belajar serta kapasitas intelektual anak usia dasar (7-11 tahun) masih bersifat konkrit atau asli, belum fantastis atau dinamis ((Bujuri, 2018; Lestari, 2018). Hal ini berarti kondisi nyata di sekitar siswa akan mengarahkan latihan pembelajaran yang signifikan dan memberikan informasi baru kepada siswa dan membuat siswa dinamis dalam 
menemukan jawaban atas masalah yang dapat dimanfaatkan dalam kehidupannya. Proses pemecahan masalah menggunakan model ini memungkinkan siswa untuk melakukan percobaan. Permasalahan nyata yang ada di sekitar siswa yang di pecahkan melalui percobaan, berdampak pada ingatan siswa bertahan lebih lama karena siswa mengalami langsung proses pemecahan masalah melalui percobaan pengaruh kalor di kehidupan seharihari. Model Problem Based Learning secara keseluruhan mempengaruhi hasil belajar IPA, khususnya dengan memberikan kebebasan untuk mengangkat masalah yang diberikan melalui tes yang dapat menyebabkan siswa beradaptasi secara mandiri dan memperoleh pengalaman sehingga ide-ide akan lebih banyak tersimpan jika siswa dapat melakukannya dengan lugas (Hidayah \& Pratiwi, 2016). Model Problem Based Learning sangat efektif digunakan dalam pembelajaran, dikarenakan model ini sangat berpengaruh untuk meningkatkan kemampuan berfikir kritis siswa, karena model Problem Based Learning mampu melatih siswa untuk merangsang cara berfikir kritis dalam menyelesaikan permasalahan yang diberikan oleh gurunya (N. P. Sari et al., 2017; Tyas, 2017).

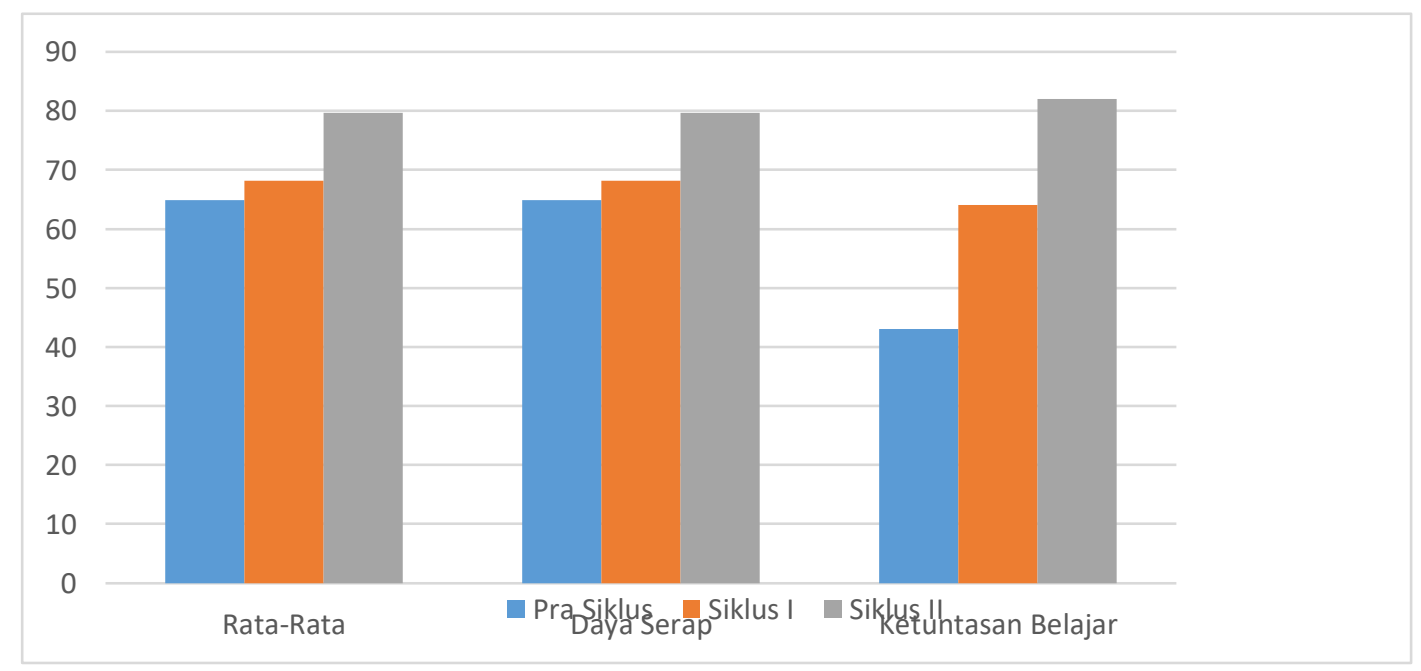

Gambar 2. Grafik Peningkatan Hasil Belajar Muatan Pelajaran IPA Pra Siklus, Siklus I, dan dan Siklus II

Pada kegiatan percobaan melalui model Problem Based Learning dengan bantuan LKPD pada muatan IPA dapat membantu siswa dalam memecahkan masalah pembelajaran yang diberikan. Kegiatan pembelajaran berbasis masalah menggunakan bantuan LKPD sebagai media sekaligus bahan ajar sangat membantu guru maupun siswa dalam melaksanakan kegiatan belajar mengajar. Dari segi guru adanya LKPD dapat membantu guru untuk mengarahkan siswa belajar dengan student centere. Sedangkan dari segi siswa adanya LKPD dapat memandu siswa dalam memecahkan masalah yang diberikan dan kegiatan pemecahan masalah menjadi terarah dan melatih siswa untuk mandiri. Penerapan pembelajaran berbasis masalah dengan bantuan LKPD membantu pendidik dalam memandu kegiatan pembelajaran karena dalam LKPD cara-cara yang harus ditempuh sudah dipikirkan sehingga siswa aktif dalam mengerjakan soal-soal yang diberikan dan membiasakan berpikir rasional untuk menangani masalah secara efektif dan mutlak serta dijadikan sebagai titik pangkal untuk mengkondisikan peserta didik terlibat secara aktif menemukan dan memahami konsep-konsep sehingga pembelajaran menjadi terarah dan bermakna (Sari \& Ma'rifah, 2020; Suratini, 2020). Dengan demikian penggunaan model Problem Based Learning berbantuan LKPD pada muatan IPA dapat bermuara pada peningkatan hasil belajar siswa. Hasil penelitian ini sejalan dengan hasil penelitian yang menyatakan bahwa penggunaan model Problem Based Learning dalam rangka meningkatkan hasil belajar muatan pelajaran IPA siswa, tetapi dalam penerapannya belum menggunakan media untuk membantu model pembelajaran yang diterapkan (Tiarini et al., 2019). Penelitian yang menyatakan bahwa penggunaan model Problem Based Learning dalam rangka meningkatkan hasil belajar kognitif siswa (Supiandi \& Julung, 2016). Penelitian yang menyatakan bahwa penggunaan media LKPD berbasis masalah pada muatan pelajaran IPA. Penelitian tersebut masih pada tahap pengembangan media LKPD dengan media cetak (Regita et al. 2020). Penelitian menyatakan bahwa Efektivitas model Problem Based Learning yaitu, siswa berperan aktif dalam pembelajaran karena dihadapkan pada permasalahan yang nyata (autentik), pembelajaran bermakna, peningkatan daya ingat, belajar mandiri, dan pembelajaran berpusat pada siswa. Implikasi tersebut tentu masih memiliki beberapa kekurangan mengingat masih adanya keterbatasan pada penelitian ini (Hasanah et al., 2021). Jadi, berdasarkan jabaran-jabaran tersebut dapat dikatakan bahwa dengan adanya model Problem Based Learning berbantuan LKPD efektif dalam meningkatkan hasil belajar hal ini disebabkan oleh dengan adanya model tersebut siswa akan belajar lebih aktif serta termotivasi. Mengingat pembelajaran PBL bersumber dari masalah-masalah yang dihadapi oleh siswa dalam kehiduopan sehari-hari. 
Pembelajan seperti ini akan memberikan pengalaman kepada siswa untuk menghadapi kehidupan sehari-hari, yang secara langsung berdampak terhadap peningkatan hasil belajar.

\section{SIMPULAN}

Model Problem Based Learning berbantuan LKPD efektif dalam meningkatkan hasil belajar muatan pelajaran IPA SD. Model Problem Based Learning pada penelitian selanjutnya diharapkan mampu diterapkan pada jenjang dan muatan pelajaran yang berbeda serta dengan menggunakan media pembelajaran inovatif lainnya.

\section{DAFTAR PUSTAKA}

Amali, K., Kurniawati, Y., \& Zlhiddah. (2019). Pengembangan Lembar Kerja Peserta Didik Berbasis Sains Teknologi Masyarakat pada Mata Pelajaran IPA di Sekolah Dasar. Journal of Natural Science and Integration, 2(2), 191-202. http://dx.doi.org/10.24014/jnsi.v2i2.8151.

Bujuri, D. A. (2018). Analisis Perkembangan Kognitif Anak Usia Dsar dan Implikasinya Dalam Kegiatan Belajar Mengajar. Jurnal Ilmu Pendidikan, https://ejournal.almaata.ac.id/index.php/LITERASI/article/view/720.

Dewi, M. P., \& Kristin, F. (2017). Meningkatkan Hasil Belajar Ipa Melalui Metode Inquiry Pada Siswa Kelas V Sd. Mimbar Sekolah Dasar, 4(1), 67-78. https://doi.org/10.53400/mimbar-sd.v4i1.6346.

Ekawati, N. P. N., Dantes, N., \& Marhaeni, A. A. I. N. (2019). Pengaruh Model Project Based Learning Berbasis 4C Membaca Pemahaman pada Siswa Kelas IV SD Gugus III Kecamatan Kediri Kabupaten Tabanan. Jurnal Pendidikan Dasar Indonesia, 3(1), 41-51. https://doi.org/10.23887/jpdi.v3i1.2866.

Fitria, H., Kristiawan, M., \& Rahmat, N. (2019). Upaya Meningkatkan Kompetensi Guru Melalui Pelatihan Penelitian Tindakan Kelas. Abdimas Unhawas, 4(1), 14-25. http://dx.doi.org/10.31942/abd.v4i1.2690.

Fuadati, M., \& Wilujeng, I. (2019). Web-Lembar Kerja Peserta Didik IPA terintegrasi potensi lokal pabrik gula untuk meningkatkan rasa ingin tahu peserta didik. Jurnal Inovasi Pendidikan IPA, 5(1), 98-108. https://doi.org/10.21831/jipi.v5i1.24543.

Hasanah, Z., Pada, A. U. T., \& Safrida. (2021). Implementasi Model Problem Based Learning Dipadu LKPD Berbasis STEM untuk Meningkatkan Keterampilan Berpikir Kritis pada Materi Pencemaran Lingkungan. Jurnal Pendidikan Sains Indonesia (Indonesian Journal of Science Education), 9(1), 65-75./ https://doi.org/10.24815/jpsi.v9i1.18134.

Hidayah, R., \& Pujiastuti, P. (2016). Pengaruh PBL Terhadap Keterampilan Proses Sains dan Hasil Belajar Kognitif pada Siswa SD. Jurnal Prima Edukasia, 4(2), 186-197. https://doi.org/10.21831/jpe.v4i2.7789.

Huda, A. I. N., \& Abduh, M. (2021). Peningkatan Hasil Belajar Menggunakan Model Pembelajaran Problem Based Learning pada Siswa Sekolah Dasar. Edukatif: Jurnal Ilmu Pendidikan, 3(4), 1594-1601. https://doi.org/10.31004/edukatif.v3i4.629.

Lestari, N. D. (2018). Pembelajaran Autentik dalam Menulis Teks Deskripsi. Jurnal Efektor, 5(2), 74-85. https://doi.org/10.29407/e.v5i2.12079.

Meilasari, S., M, D., \& Yelianti, U. (2020). Kajian Model Pembelajaran Problem Based Learning (PBL) dalam Pembelajaran di Sekolah. Jurnal Pendidikan Biologi Dan Sains, 3(2), 195-207. https://journal.ipm2kpe.or.id/index.php/BIOEDUSAINS/article/view/1849.

Naimah, J., Winarni, D. S., \& Widiyawati, Y. (2019). Pengembangan Game Edukasi Science Adventure Untuk Meningkatkan Keterampilanpemecahan Masalah Siswa. Jurnal Pendidikan Sains Indonesia (Indonesian Journal of Science Education), 7(2), 91-100. https://doi.org/10.24815/jpsi.v7i2.14462.

Nelvianti, \& Fitria, Y. (2020). Karakteristik Model Problem Based Learning Berbantuan E-learning Portal Rumah Belajar pada Pembelajaran IPA Tematik. Pedagogia: Jurnal Ilmu Pendidikan, 18(02), 162-172. https://doi.org/10.17509/pdgia.v18i2.31367.

Oktaviani, L., \& Tari, N. (2018). Penerapan Model Pembelajaran Berbasis Masalah Untuk Meningkatkan Kemampuan Pemecahan Masalah IPA pada Siswa Kelas VI SD No 5 Jineng Dalem. Jurnal Ilmu Pendidikan, 16(1), 10-15. https://doi.org/10.17509/pdgia.v16i1.10718.

Pramudya, E., Kristin, F., \& Anugraheni, I. (2019). Peningkatan keaktifan dan hasil belajar ipa pada pembelajaran tematik menggunakan pbl. Jurnal Kajian Penelitian Dan Pendidikan Dan Pembelajaran, 3(2), 320-329. https://doi.org/10.35568/naturalistic.v3i2.391.

Prihantoro, A., \& Hidayah, F. (2019). Melakukan Penelitian Tindakan Kelas. Jurnal Ilmu-Ilmu Keislaman, 9(1), 4960. /https://doi.org/10.47200/ulumuddin.v9i1.283.

Putri, A. A. A., Swatra, I. W., \& Tegeh, I. M. (2018). Pengaruh Model Pembelajaran PBL Berbantuan Media Siswa Kelas III SD. 1(1), 21-32. http://dx.doi.org/10.23887/mi.v23i1.16407.

Regita C, Pramesthi, D., Hakim, A. R., \& Triwahyuningtyas, D. (2020). Pengembangan Lembar Kerja Peserta Didik (LKPD) Pada Pembelajaran Ipa Berbasis Masalah Pada Kelas IV Sekolah Dasar. Prosiding Seminar 

Nasional $\quad$ UGSD
https://conference.unikama.ac.id/artikel/index.php/pgsd/article/view/511.

4, 291-303

Rosidah, C. T. (2018). Penerapan Model Problem Based Learning untuk Menumbuhkembangkan Higher Order Thinking Skill Siswa. Jurnal Inventa, 2(1), 62-71. https://doi.org/10.36456/inventa.2.1.a1627.

Sari, N. P., Budijanto, B., \& Amiruddin, A. (2017). Pengaruh Penerapan Model Pembelajaran Problem Based Learning Dipadu Numbered Heads Together Terhadap Keterampilan Metakognitif Dan Kemampuan Berpikir Kritis Geografi Siswa SMA. Jurnal Pendidikan: Teori, Penelitian, Dan Pengembangan, 2(3), 440447. http://journal.um.ac.id/index.php/jptpp/article/view/8720.

Sari, W. P., \& Ma'rifah, D. R. (2020). Pengembangan Lkpd Mobile Learning Berbasis Android Dengan Pbl Untuk Meningkatkan Critical Thinking Materi Lingkungan. Jurnal Pendidikan Biologi, 11(2), 49. /http://dx.doi.org/10.17977/um052v11i2p49-58.

Setiadi, H. (2016). pelaksanaan penilaian pada kurikulum 2013 the implementation of assessment in the curriculum 2013 Jural Penelitian Dan Evaluasi Pendidikan, 20(2), 166-178. https://doi.org/10.21831/pep.v20i2.7173.

Silitonga, B. N. (2020). edagogia Jurnal Ilmu Pendidikan. Pedagogia: Jurnal Ilmu Pendidikan, 18(01), 1-12. https://doi.org/10.17509/pdgia.v18i1.23335.

Siswanto. (2017). Penilaian dan Pengukuran Sikap dan Hasil Belajar Peserta Didik. Bosscript.

Sufiyanto, M. I. (2020). Pembelajaran IPA SD/MI. Manggu.

Supiandi, M. I., \& Julung, H. (2016). Pengaruh Model Problem Based Learning (PBL) terhadap Kemampuan Memecahkan Masalah dan Hasil Belajar Kognitif Siswa Biologi SMA. JPS (Jurnal Pendidikan Sains), 4(2), 60-64. https://doi.org/10.17977/jps.v4i2.8183

Suratini. (2020). Penerapan Problem Based Learning Berbantuan LKPD Pada Materi-Materi Pencemaran Lingkungan. Jurnal Penelitian Pendidikan Indonesia, 5(2), 1-7. https://irpp.com/index.php/jpp/article/view/1102.

Syafriana, D. (2017). Penerapan Model Problem Based Learning (PBL) dalam Pendekatan Saintifik Untuk Meningkatkan Hasil Belajar IPA Kelas V SDN 63 Surabaya. Jurnal Inovasi Pendidikan Dan Pembelajaran Sekolah Dasar, 1(1), 30-43. https://doi.org/10.24036/jippsd.v1i1.7932.

Tiarini, N. P., Dantes, N., \& Yudiana, K. (2019). Pengaruh Model Pembelajaran Problem Based Learning (PBL) Berorientasi Tri Hita Karana Terhadap Hasil Belajar IPA. Jurnal Mimbar Ilmu, 24(3), 300-309. https://doi.org/10.23887/pips.v3i1.2879.

Tyas, R. (2017). Kesulitan Penerapan Problem Based Learning Dalam Pembelajaran Matematika. Tecnoscienza, 2(1), 43-52. https://ejournal.kahuripan.ac.id/index.php/TECNOSCIENZA/article/view/26.

Wahyuningtyas, R., \& Kristin, F. (2021). Meta Analisis Penerapan Model Pembelajaran Problem Based Learning Terhadap Motivasi Belajar. Mimbar PGSD Undiksha, 9(1), 49-55. http://dx.doi.org/10.23887/jjpgsd.v9i1.32676.

Wardani, R. F. A. K., Rifai, M., \& Mandalawati, T. K. (2017). Efektivitas Model Pembelajaran Clis Berbantuan Media Slide Powerpoint Terhadap Hasil Belajar IPA. Premiere Educandum: Jurnal Pendidikan Dasar Dan Pembelajaran, 7(02), 104. https://doi.org/10.25273/pe.v7i2.1596.

Wicaksono, A. G., Jumanto, \& Irmade, O. (2020). Pengembangan Media Komik Komsa Materi Rangka pada Pembelajaran IPA di Sekolah Dasar. PE:Jurnal Pendidikan Dasar Dan Pembelajaran, 10(2), 215-226. https://doi.org/10.25273/pe.v10i2.6384.

Yunitasari, I., \& Hardini, A. T. A. (2020). Penerapan Model PBL untuk Meningkatkan Keaktifan Peserta Didik dalam Pembelajaran Daring di Sekolah Dasar. Jurnal Basicedu, 3(2), 524-532. https://doi.org/10.31004/basicedu.v5i4.983.

Zakia, R., Khaldun, I., \& Safitri, R. (2018). Pengaruh Problem Based Learning Melalui School Watching Terhadap Aktivitas dan Hasil Belajar Siswa Pada Materi Asam Basa di SMP. Jurnal Pendidikan Sains Indonesia, 6(1), 46-54. https://doi.org/10.24815/jpsi.v6i1.10748. 